\title{
Detrimental effects of low atmospheric humidity and forest fire on a community of western Himalayan butterflies
}

\author{
Peter Smetacek \\ The Butterfly Research Centre, The Retreat, Jones Estate, Bhimtal, Nainital, Uttarakhand 263136, India \\ Email: petersmetacek@rediffmail.com
}

Date of publication (online): 26 April 2011 Date of publication (print): 26 April 2011 ISSN 0974-7907 (online) | 0974-7893 (print)

Editor: George Mathew

\section{Manuscript details:}

Ms \# 02307

Received 07 September 2009

Final received 02 January 2011

Finally accepted 10 March 2011

Citation: Smetacek, P. (2011). Detrimental effects of low atmospheric humidity and forest fire on a community of western Himalayan butterflies. Journal of Threatened Taxa 3(4): 1694-1701.

Copyright: (C Peter Smetacek 2011. Creative Commons Attribution 3.0 Unported License. JoTT allows unrestricted use of this article in any medium for non-profit purposes, reproduction and distribution by providing adequate credit to the authors and the source of publication.

Author Details: Peter SMETACEK runs the Butterfly Research Centre in Bhimtal, Uttarakhand. He has worked on Lepidoptera for more than 30 years and has published 50 scientific papers. He is the first Indian to discover and describe a butterfly taxon, Neptis miah varshneyi. He has described a dozen moths and butterflies new to science.

Acknowledgements: I am grateful to the Rufford Small Grant Foundation, U.K. for funding this work; to Ashok K. Nayak of the Directorate of Coldwater Fisheries Research, Bhimtal for rainfall data and to the anonymous referees whose comments considerably improved this paper.
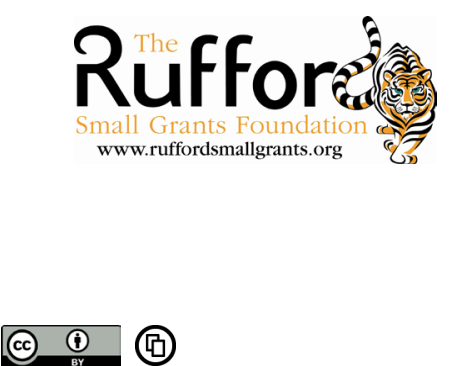

OPEN ACCESS | FREE DOWNLOAD
Abstract: Compared to previous years, the period from October 2008 to March 2009 showed marked reductions in species number and population size in the butterfly community of the Maheshkhan Reserve Forest, Nainital District, Uttarakhand. Desiccation of pupae due to abnormally low atmospheric humidity after the failure of seasonal rains appears to have been a major cause of this reduction. The drop in humidity also appears to be linked to the unusual spread of fires affecting broadleaf forests, one of which in May 2009 wiped out the remaining Maheshkhan butterfly community.

Keywords: Climate change, forest fire, Himalaya, Kumaon, Lepidoptera, pupal desiccation.

\section{INTRODUCTION}

The Kumaon Himalaya adjoin the western border of Nepal, and along with the Garhwal Himalaya further west comprise the Indian state of Uttarakhand. In Nainital District of the Kumaon Himalaya the Gagar range is southernmost, rising from the Gangetic plain at roughly $400 \mathrm{~m}$ elevation to Naini Peak near the town of Nainital at an elevation of $2600 \mathrm{~m}$. Rainfall is heavy, between $2029 \mathrm{~mm}$ and $3048 \mathrm{~mm}$ (80 to 120 inches) annually (Osmaston 1927) with $80 \%$ of the precipitation received during the south west monsoon between June and September, while 20\% arrives during the remainder of the year, mostly during a fortnight of winter rains in January or February.

Maheshkhan Reserve Forest (roughly at $29^{\circ} 26^{\prime} 7^{\prime \prime} \mathrm{N} \& 7^{\circ} 35^{\prime} 40^{\prime \prime} \mathrm{E}$ ) lies west of the town of Bhowali, extending from the crest of the Gagar range and Gagar Peak $(2400 \mathrm{~m})$ to the village of Shyamkhet (roughly $1800 \mathrm{~m}$ ). The forest comprises of a mix of Chir Pine (Pinus roxburghii) and dense subtropical evergreen forests of Himalayan oaks (Quercus floribunda, $Q$. leucotrichophora and Q. glauca) and other species (Alnus nepalensis, Rhododendron arboreum, Pieris ovalifolia, etc.). This forest is the headwaters of the Khalsa River, which is a perennial rain-fed tributary of the Gola River.

Besides many butterfly species, the forest is home to mammals such as Sambar and muntjacs, leopards, common langurs, yellow-throated martens, with occasional reports of Himalayan Black Bear.

The Maheshkhan forest has been visited sporadically during the spring and summer months since 1986. During the 24 years, the forest was visited more than 100 times during the summer months from March to June. During the summer months, there are often swarms of butterflies in the ravines and along streams of this forest. As soon as the south west 
monsoon reaches and the rainy season begins in June, the butterflies stop congregating at water. Evidence from my breeding experiments indicates that there are broods of most species during the rainy season, but not as numerous as the spring and summer broods. The individuals comprising these broods do not congregate at water and are not as frequently seen as the dry season spring and summer broods.

Weather parameters, particularly atmospheric humidity, are known to have a decisive effect on biodiversity. This is usually amply illustrated with the textbook comparison of faunal diversity of hot deserts on one hand, with tropical rainforest communities on the other. Butterflies, too, occur in greater variety and profusion in areas of heavy rainfall as compared with low rainfall areas. For example within India the northeastern states are home to over a thousand species of butterflies, compared to the plains of Uttar Pradesh with less than a hundred, or the Thar Desert with less than 50 species (Peile 1937). While the effect of humidity on such extensive landscapes is well known, relatively little is known about factors that limit the abundance and distribution of butterfly species within smaller landscapes, such as hillsides or forests. In this study, an attempt is made to evaluate the effect of reduced atmospheric humidity on butterfly populations in the Maheshkhan Reserve Forest in the Kumaon Himalaya.

\section{MATERIALS AND METHODS}

Data pertaining to butterfly population trends in this forest area has been generated through observations made during past visits since 1986. During 2009, a rigorous survey was made for 65 days during March to May. The forest was surveyed from 1000 to 1400 $\mathrm{hr}$, after which butterfly activity is greatly reduced. Since dawn and dusk is the period of activity for most Grypocera (Hesperiidae), these are not included in this paper, although a few species were observed during the daytime.

\section{OBSERVATIONS}

The observations were mainly made during the summer months from April to June when butterflies congregate in the ravines and along streams of this forest and are consequently easily observed. Certain species like Lasiommata schakra (Kollar) do not visit water, but these butterflies were encountered along paths and elsewhere in the forest. Also, not much attention was paid to groups such as Yphthima Hübner; Mycalesis Hübner; Eurema Hübner, etc. A single specimen of the recently described taxon Ypthima kedarnathensis Singh was recorded in Maheshkhan (Smetacek 2010). A list of butterfly species observed in Maheshkhan Reserve Forest since 1989 is given in Table 1. However, Y. kedarnathensis has not been included in Table 1 pending confirmation of its taxonomic status.

In 2009, the winter rains failed (Table 2), with practically no precipitation between the end of September 2008 and April 2009, resulting in a rather dry spring and summer 2009. Although there were very meager rains during the winter of 1998-1999, due to which some annuals did not germinate the following spring causing a drop in numbers of a butterfly species dependent on them (Smetacek 2002), the effects on butterfly populations then were by no means so widespread or as severe as experienced during spring and summer 2009 due, evidently, to the failed winter rains. The State Government officially declared the district to be affected by drought in 2009 .

I had the good fortune to visit the forest rather frequently in spring and summer 2009, due to which it was possible to track the presence or absence of the butterfly species that make up the community there. As the season progressed, it became evident that the reduced number of species and butterflies was not solely a matter of delayed emergence caused by the lack of sufficient atmospheric humidity, but a matter of desiccated pupae resulting in the death of butterflies before they could emerge. This became evident when all the overwintering pupae I had bred the previous autumn dried out and died by April 2009. Even pupae formed by larvae in April 2009, which should have emerged the following month, dried out and died. Upon opening the pupae, I found fully developed but desiccated moths that had not managed to emerge (Unfortunately, it was not possible to identify them since the wings had not expanded). Only a single overwintering Hyles nicaea lathyrus (Walker) (Lepidoptera: Sphingidae) pupa from the cold desert of Ladakh survived to emerge on 19 May. No doubt, 
Table 1. Butterflies recorded from Maheshkhan Reserve Forest, Nainital District, between 1989 and 2009 and their status in general and in summer 2009.

\begin{tabular}{|c|c|c|c|}
\hline Species & Earlier status & $\begin{array}{l}\text { Status in } \\
\text { summer } 2009\end{array}$ & Remarks \\
\hline \multicolumn{4}{|l|}{ Papilionidae } \\
\hline Atrophaneura aidoneus Doubleday & Not rare & Not rare & Stable population. Larval food plant (LFP) Aristolochia dilatata. \\
\hline Byasa polyeuctes Doubleday & Absent & Not rare & Highly unstable population. LFP as above. \\
\hline Byasa dasarada Moore & Common & Common & Population reduced over the years. LFP as above. \\
\hline Papilio agestor Gray & Not rare & Not rare & Stable population. LFP Persea duthiei. \\
\hline Papilio protenor Cramer & Not rare & Not rare & Only spring brood recorded. LFP Zanthoxylum. \\
\hline Papilio demoleus Linnaeus & Recorded once & & Straggler from low elevation. \\
\hline Graphium sarpedon Linnaeus & Rare & Absent & Not regularly seen at water. \\
\hline Graphium cloanthus Westwood & Rare & Absent & Might be commoner at canopy level. \\
\hline Pazala cashmirensis Rothschild & Common & Common & Stable population. LFP Machilus duthiei. \\
\hline \multicolumn{4}{|l|}{ Pieridae } \\
\hline Pieris brassicae Linnaeus & Common & Common & Not frequently met within the forest. \\
\hline Artogeia canidia Sparrman & Common & Common & More frequent than Pieris brassicae within the forest. \\
\hline Aporia soracta Moore & Recorded & Absent & Recorded during the 1980 s. \\
\hline Aporia agathon Gray & Very common & Not rare & $\begin{array}{l}\text { Normally swarms, much reduced population in the year } 2009 \text {. } \\
\text { LFP Berberis chitra. }\end{array}$ \\
\hline Delias belladonna Fabricius & Common & Rare & A few in April 2009. Flies before $D$. sanaca. \\
\hline Delias sanaca Moore & Very common & Absent & Normally swarms. Entirely absent in the year 2009. \\
\hline Gonepteryx rhamni Linnaeus & Common & Common & $\begin{array}{l}\text { Common in early spring. Stable population in the year } 2009 . \\
\text { Overwinters as an imago. }\end{array}$ \\
\hline Eurema hecabe Linnaeus & Not rare & Not rare & Recorded occasionally within the forest. \\
\hline Colias fieldii Ménétries & Common & Not rare & Somewhat scarcer in 2009 than in previous years. \\
\hline Anaphaeis aurota Fabricius & Not rare & Not rare & Migrant \\
\hline Catopsilia pomona Fabricius & Not rare & Not rare & Migrant \\
\hline Pontia daplidice Linnaeus & Not rare & Absent & Highly susceptible to drought. \\
\hline \multicolumn{4}{|l|}{ Nymphalidae } \\
\hline Parantica aglea Cramer & Rare & Absent & Infrequent in the forest in good years. \\
\hline Parantica sita Kollar & Rare & Absent & Rarely met in spring. \\
\hline Euploea mulciber Cramer & Rare & Absent & Very occasionally seen in the forest. \\
\hline Danaus chrysippus Linnaeus & Rare & Absent & Stragglers from lower elevation. \\
\hline Danaus genutia Cramer & Rare & Absent & Stragglers from lower elevation. \\
\hline \multicolumn{4}{|l|}{ Satyrinae } \\
\hline Mycalesis francisca sanatana Moore & Not rare & Absent & Nomally a stable population, but none seen in the year 2009 . \\
\hline Zophoessa sidonis vaivarta Doherty & Not rare & Not rare & A few seen in spring 2009. \\
\hline Lethe insana Kollar & Rare & Rare & A few in spring 2009 \\
\hline Lethe verma Kollar & Common & Rare & Very much scarcer than in other years. \\
\hline Lasiommata schakra Kollar & Not rare & Not rare & A few about in spring. \\
\hline Orinoma damaris Gray & Rare & Absent & A forest insect. None seen in the year 2009. \\
\hline Erebia annada Moore & Not rare & Absent & None of the spring or summer broods seem to have emerged. \\
\hline Erebia nirmala Moore & Very common & Not rare & Very few about in the year 2009 compared to normal years. \\
\hline Yphthima nikaea Moore & Common & Not rare & $\begin{array}{l}\text { As abundant as E. nirmala in some years. Only a few about in } \\
\text { the year } 2009 .\end{array}$ \\
\hline Melanitis leda Drury & Rare & Rare & $\begin{array}{l}\text { At the upper extremity of its distribution. A few were about in the } \\
\text { year } 2009 \text {. }\end{array}$ \\
\hline Neope pulaha Moore & Not common & Absent & The spring brood was absent in the 2009 . \\
\hline
\end{tabular}




\begin{tabular}{|c|c|c|c|}
\hline Species & Earlier status & $\begin{array}{l}\text { Status in } \\
\text { summer } 2009\end{array}$ & Remarks \\
\hline \multicolumn{4}{|l|}{ Nymphalinae } \\
\hline Polyura dolon Westwood & Rare & Absent & None seen in 2009. \\
\hline Sephisa dichroa Kollar & Not common & Absent & None seen in 2009. \\
\hline Limbusa patala Kollar & Not common & Absent & None seen in 2009. \\
\hline Auzakia danava Moore & Not common & Absent & None seen in 2009. \\
\hline Athyma opalina Kollar & Common & Not common & A few about in spring 2009. \\
\hline Neptis mahendra Moore & Not common & Absent & None seen in 2009. \\
\hline Neptis sappho Pallas & Common & Absent & Normally several about, but none in the year 2009 . \\
\hline Neptis soma Moore & Common & Absent & Also entirely absent in the year 2009. \\
\hline Neptis sankara Kollar & Common & Absent & Quite frequent at water normally, none seen in 2009. \\
\hline Neptis ananta Moore & Not rare & Absent & $\begin{array}{l}\text { Rather less common than other Neptini, none seen in the year } \\
2009 .\end{array}$ \\
\hline Neptis narayana Moore & Common & Very rare & Only a single individual seen in the year 2009 . \\
\hline Cyrestis thyodamas Kollar & Common & Not rare & A few about in spring 2009. \\
\hline Pseudergolis wedah Kollar & Rare & Absent & None seen in the year 2009. \\
\hline Junonia iphita Cramer & Common & Rare & Much reduced in numbers in the year 2009. \\
\hline Vanessa cardui Linnaeus & Not rare & Rare & A few about in spring 2009. \\
\hline Vanessa indica Herbst & Common & Rare & Much less frequently met than in other years. \\
\hline Vanessa canace Linnaeus & Common & Common & $\begin{array}{l}\text { Several, perhaps belonging to a single batch of eggs, on the } \\
\text { wing together in summer } 2009 .\end{array}$ \\
\hline Aglais cashmirensis Kollar & Not rare & Absent & None seen in 2009 , although this is normally a common insect. \\
\hline Symbrenthia niphanda Moore & Rare & Absent & Only recorded once in 1998. Absent in the year 2009. \\
\hline Childrena childreni Gray & Not rare & Absent & Several usually about in summer. None about in the year 2009. \\
\hline Issoria issaea Doubleday & Rare & Absent & $\begin{array}{l}\text { Recorded occasionally, but not usually met within the forest. } \\
\text { None about in the year } 2009 \text {. }\end{array}$ \\
\hline Phalanta phalantha Drury & Very rare & Absent & Straggler from lower elevation. \\
\hline Acraea vesta Fabricius & Common & Absent & $\begin{array}{l}\text { A large brood usually emerges in summer. None in the year } \\
2009 .\end{array}$ \\
\hline Libythea lepita Moore & Common & Absent & $\begin{array}{l}\text { Several usually about in early spring. None about in the year } \\
2009 .\end{array}$ \\
\hline \multicolumn{4}{|l|}{ Lycaenidae } \\
\hline Dodona durga Kollar & $\begin{array}{l}\text { Extremely } \\
\text { common }\end{array}$ & Common & $\begin{array}{l}\text { The only butterfly about in any numbers in the year } 2009 \text {, but } \\
\text { still, much fewer than in other years. }\end{array}$ \\
\hline Dodona dipoea Hewitson & Common & Common & More or less as common as in other years. \\
\hline Dodona eugenes Bates & Common & Common & More or less as common as in other years. \\
\hline Dodona ouida Moore & Rare & Absent & None seen in the year 2009. \\
\hline Abisara fylla Doubleday & Rare & Rare & A few about in early spring. \\
\hline Acytolepis puspa Horsfield & Not rare & Absent & None seen in the year 2009. \\
\hline Arletta vardhana Moore & Rare & Absent & None about in the year 2009. \\
\hline Udara albocaerulea Moore & Rare & Absent & None about in the year 2009. \\
\hline Celastrina argiolus Linnaeus & Common & Absent & $\begin{array}{l}\text { None seen in the year } 2009 \text {, although this is normally quite a } \\
\text { common butterfly. }\end{array}$ \\
\hline Celastrina huegelii Moore & Common & Common & Common about its LFP, Princepia utilis and thistle flowers. \\
\hline Celastrina gigas Hemming & Common & Common & Found in company with $C$. huegelii. Similarly abundant. \\
\hline Aricia agestis Denis \& Schiffermuller & Rare & Absent & None seen in the year 2009. \\
\hline Pseudozizeeria maha Kollar & Common & Absent & Surprisingly, none seen in the year 2009 . \\
\hline Lampides boeticus Linnaeus & Very common & Common & A migrant. \\
\hline
\end{tabular}




\begin{tabular}{|c|c|c|c|}
\hline Species & Earlier status & $\begin{array}{l}\text { Status in } \\
\text { summer } 2009\end{array}$ & Remarks \\
\hline Heliophorus sena Kollar & Common & Absent & $\begin{array}{l}\text { A local butterfly found near its LFP, Rumex hastatus. None about } \\
\text { in the year } 2009 .\end{array}$ \\
\hline Euaspa milionia Hewitson & Rare & Absent & None seen in the year 2009 . \\
\hline Euaspa ziha de Niceville & Very common & Absent & Swarms in some years. Never absent until in the year 2009 . \\
\hline Chrysozephyrus ataxus Doubleday & Not rare & Absent & Not a single one seen in the year 2009 . \\
\hline Chrysozephyrus birupa Moore & Not rare & Absent & Scarcer than C. syla. Entirely absent in the year 2009. \\
\hline Chrysozephyrus syla Kollar & Very Common & Absent & Normally difficult to miss, but entirely absent in the year 2009 . \\
\hline Arhopala dodonea Moore & Common & Common & A few about at water in early spring. \\
\hline Arhopala rama Kollar & Common & Common & A few about at water in spring. \\
\hline Panchala ganesa Kollar & $\begin{array}{l}\text { Extremely } \\
\text { common }\end{array}$ & Very rare & $\begin{array}{l}\text { Swarms by the hundred every year. Only three specimens seen } \\
\text { in the year } 2009 .\end{array}$ \\
\hline Spindasis nipalicus Moore & Not rare & Rare & Regular visitor to water: only one seen in the year 2009. \\
\hline Lycaena pavana Kollar & Not rare & Absent & None seen in the year 2009. \\
\hline Chaetoprocta odata Hewitson & Rare & Absent & None seen in the year 2009. \\
\hline Pratapa ctesia Hewitson & Rare & Absent & None seen in the year 2009. \\
\hline Pratapa icetas Hewitson & Not rare & Absent & None seen in the year 2009 . \\
\hline Tajuria illurgioides de Niceville & Rare & Absent & None seen in the year 2009. \\
\hline Horaga onyx Moore & Rare & Rare & A single individual seen in the year 2009 . \\
\hline Chliaria kina Hewitson & Rare & Absent & None seen in the year 2009. \\
\hline Rapala manea schistacea Moore & Not common & Absent & Normally rather frequently met, but none seen in the year 2009 . \\
\hline Rapala selira Moore & Not common & Absent & None seen in the year 2009. \\
\hline Rapala nissa Kollar & Not common & Absent & Regularly seen in other years, but none in the year 2009 . \\
\hline
\end{tabular}

Table 2. District rainfall (mm.) for last five years of Nainital District (Anonymous 2010)

\begin{tabular}{|c|c|c|c|c|c|c|c|c|c|c|c|c|}
\hline Year & January & February & March & April & May & June & July & August & September & October & November & December \\
\hline & $\begin{array}{l}\text { R/F \% } \\
\text { Dep. }\end{array}$ & $\begin{array}{l}\text { R/F \% } \\
\text { Dep. }\end{array}$ & $\begin{array}{l}\text { R/F \% } \\
\text { Dep. }\end{array}$ & $\begin{array}{l}\text { R/F \% } \\
\text { Dep. }\end{array}$ & $\begin{array}{l}\text { R/F \% } \\
\text { Dep. }\end{array}$ & $\begin{array}{c}\text { R/F \% } \\
\text { Dep. }\end{array}$ & $\begin{array}{c}\text { R/F \% } \\
\text { Dep. }\end{array}$ & $\begin{array}{l}\text { R/F \% } \\
\text { Dep. }\end{array}$ & $\begin{array}{l}\text { R/F \% } \\
\text { Dep. }\end{array}$ & $\begin{array}{l}\text { R/F \% } \\
\text { Dep. }\end{array}$ & $\begin{array}{l}\text { R/F \% } \\
\text { Dep. }\end{array}$ & $\begin{array}{l}\text { R/F \% } \\
\text { Dep. }\end{array}$ \\
\hline 2005 & $\begin{array}{c}46.9 \\
-8\end{array}$ & $\begin{array}{c}71.4 \\
68\end{array}$ & $\begin{array}{l}27.1 \\
-33\end{array}$ & $\begin{array}{c}24.8 \\
6\end{array}$ & $\begin{array}{c}33.5 \\
-41\end{array}$ & $\begin{array}{l}67.9 \\
-69\end{array}$ & $\begin{array}{c}467.3 \\
-14\end{array}$ & $\begin{array}{c}292.2 \\
-40\end{array}$ & $\begin{array}{c}404.0 \\
48\end{array}$ & $\begin{array}{l}14.5 \\
-80\end{array}$ & $\begin{array}{c}0.0 \\
-100\end{array}$ & $\begin{array}{l}7.9 \\
-53\end{array}$ \\
\hline 2006 & $\begin{array}{r}4.4 \\
-91\end{array}$ & $\begin{array}{l}0.3 \\
-99\end{array}$ & $\begin{array}{c}62.3 \\
55\end{array}$ & $\begin{array}{l}10.8 \\
-54\end{array}$ & $\begin{array}{c}102.3 \\
81\end{array}$ & $\begin{array}{c}108.4 \\
-51\end{array}$ & $\begin{array}{c}295.0 \\
-46\end{array}$ & $\begin{array}{c}317.4 \\
-35\end{array}$ & $\begin{array}{c}88.4 \\
-68\end{array}$ & $\begin{array}{l}15.9 \\
-78\end{array}$ & $\begin{array}{l}4.3 \\
-14\end{array}$ & $\begin{array}{c}13.4 \\
-20\end{array}$ \\
\hline 2007 & $\begin{array}{c}152.7 \\
259\end{array}$ & $\begin{array}{c}121.6 \\
202\end{array}$ & $\begin{array}{c}33.7 \\
44\end{array}$ & $\begin{array}{c}71.7 \\
27\end{array}$ & $\begin{array}{c}198.4 \\
-9\end{array}$ & $\begin{array}{c}262.8 \\
-52\end{array}$ & $\begin{array}{c}420.5 \\
-13\end{array}$ & $\begin{array}{c}259.1 \\
-5\end{array}$ & $\begin{array}{l}11.7 \\
-84\end{array}$ & $\begin{array}{c}0.0 \\
-100\end{array}$ & $\begin{array}{l}2.2 \\
-87\end{array}$ & \\
\hline 2008 & $\begin{array}{c}10.2 \\
-80\end{array}$ & $\begin{array}{l}4.5 \\
-89\end{array}$ & $\begin{array}{l}0.9 \\
-98\end{array}$ & $\begin{array}{l}22.3 \\
-5\end{array}$ & $\begin{array}{c}38.5 \\
-32\end{array}$ & $\begin{array}{c}333.6 \\
52\end{array}$ & $\begin{array}{c}495.9 \\
-9\end{array}$ & $\begin{array}{c}527.0 \\
9\end{array}$ & $\begin{array}{c}353.1 \\
29\end{array}$ & $\begin{array}{l}11.5 \\
-84\end{array}$ & $\begin{array}{l}4.7 \\
-6\end{array}$ & $\begin{array}{c}0.0 \\
-100\end{array}$ \\
\hline 2009 & $\begin{array}{l}0.6 \\
-99\end{array}$ & $\begin{array}{l}14.3 \\
-66\end{array}$ & $\begin{array}{l}3.2 \\
-92\end{array}$ & $\begin{array}{c}22.2 \\
-5\end{array}$ & $\begin{array}{c}51.4 \\
-9\end{array}$ & $\begin{array}{l}62.6 \\
-71\end{array}$ & $\begin{array}{c}226.2 \\
-59\end{array}$ & $\begin{array}{c}493.7 \\
2\end{array}$ & $\begin{array}{c}301.0 \\
10\end{array}$ & $\begin{array}{c}194.1 \\
164\end{array}$ & $\begin{array}{l}24.7 \\
394\end{array}$ & $\begin{array}{l}2.8 \\
-83\end{array}$ \\
\hline
\end{tabular}

being a xerophytic species, it found nothing unusual in the dryness of spring and summer.

The Chir Pine forest patches in the Reserve Forest burnt twice in 2009: once in April, when the humus of the previous year burnt and again a fortnight later in May, when the trees shed their resinous needles. In one major fire in May, even the broadleaf forest burnt over most of the area, after which butterfly populations dropped almost to zero and I discontinued observations. The fact that forest fires in broadleaf forests resulted in an almost total decimation of the butterfly population, while regular annual fires in Chir Pine forests in the adjoining areas do not greatly affect butterfly populations, strongly suggests that the butterfly populations concerned do not depend on Chir Pine forest for survival. Once broadleaf forests begin to 
burn, the effect on insect biodiversity is devastating.

\section{DISCUSSION}

The Maheshkhan Reserve Forest has changed little during the more than two decades it has been studied. Cattle, which were frequently met during the 1990s, are now absent but local women lopping broadleaf trees for cattle fodder are met more frequently than 20 years ago. On the whole it is a well preserved forest, and with perennial streams rising in some of the ravines presents a most interesting case study for what a forest should be like in order to regulate the water regime of perennial rain fed springs and streams in this area. Over the years a total of 95 butterfly species have been identified with certainty from this forest. Many are common and some which are reportedly rare or even very rare in other parts of their range, such as Neptis narayana and Euaspa ziha (Evans 1932) are common.

The only thing that changed in 2009 compared with earlier years was that the winter rains failed, although Maheshkhan got a sprinkling of snow on 12 February 2009 (Image 1). This was evidently not enough to offset the dryness experienced during March to May, which caused the State Government to declare a state of drought in the district in May. On the basis of the fact that all the pupae from different areas in Nainital district that I had overwintering indoors dried out in Bhimtal, roughly $20 \mathrm{~km}$ away, it is reasonable to assign a similar reason to the failure of the spring and summer broods of 50 species comprising $52.6 \%$ of the total species recorded from this forest.

The most conspicuous absence was of Delias sanaca, which is extremely common every summer. To give an idea of the numbers involved, I discovered many dead butterflies in a small stream in the forest on 04 June 1998, presumably poisoned by pesticides infiltrating into the water from apple orchards on the other side of the hill. The figures of dead individuals from my notes are: Delias sanaca 200+; Aporia agathon $200+$. There were still many more individuals of both species flying about on that and subsequent days. While $D$. sanaca presumably feeds on members of the parasitic Loranthaceae in the larval stage, $A$. agathon has been recorded on Berberis chitra in the area. In the summer of 2009 , there were some $A$.

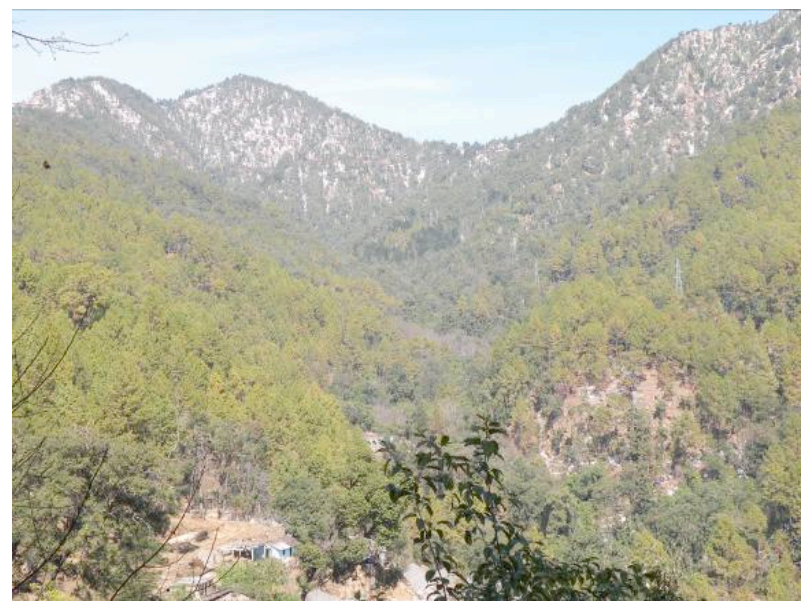

Image 1. A part of Maheshkhan Reserve Forest under a sprinkling of snow in February 2009. Light green foliage of Chir Pine; darker green of broadleaf forest, mainly Himalayan Oak. Gagar Pass $(2400 \mathrm{~m})$ at the lowest part of the skyline.

agathon about, but very many fewer individuals than was usually the case. Both these species appear to be univoltine in the area. The eggs of $A$. agathon are laid in batches of up to a hundred. Two batches of these eggs located on leaves of Berberis chitra in May 2009 and left in situ failed to hatch out, presumably due to desiccation. One could therefore predict that there would be a reduced number of $A$. agathon about in the spring and summer of 2010.

The Neptini were another interesting discovery. For more than 20 years, I have observed the following species regularly in the forest. $N$. narayana is usually common, as common as $N$. sankara. $N$. ananta usually is about in fewer numbers. To give an idea of numbers, one might see around $20 \mathrm{~N}$. narayana every day for a few weeks in May and June; roughly the same number of $N$. sankara and perhaps three to four individuals of $N$. ananta a day during the same period. While the larval host plants of $N$. narayana, $N$. sankara, $N$. ananta and $N$. mahindra in the area are unknown, $N$. soma feeds on Celtis australis (Wynter-Blyth 1957 as N. yerburyi). Normally this group is found in hilly regions with moderate to heavy rainfall, attaining their greatest diversity in the wetter part of North Eastern India and Indo-China. Their nearly complete absence during 2009 strongly suggests that their overwintering stages are susceptible to desiccation, which is probably a major factor restricting their range to wetter regions.

Of the butterflies that managed to maintain their 
population levels in 2009, Dodona dipoea and $D$. eugenes are noteworthy, since their allies, $D$. durga and $D$. ouida seem to have suffered. The former two, although bred on bamboo in the Mussoorie area in Garhwal (Mackinnon \& de Nicéville 1897-1898), have only been bred on the plant Myrsine semiserrata in this area (mihi). This plant grows in damp, shady ravines, where the larvae were apparently not only preserved from desiccation but also from forest fires.

The Troidini are of interest, since 2009 marked the re-appearance in Maheshkhan of Byasa polyeuctes after a gap of nearly 20 years. Byasa dasarada and Atrophaneura aidoneus were about in the usual numbers. The absence of Troides aeacus from Maheshkhan Reserve Forest is noteworthy, since it feeds on the same species of Aristolochia as the other Troidini mentioned above (mihi). It was seen on the northern face of the range during the 1970s and is common in pockets in other parts of the Gagar range.

The Lycaenidae as a whole appear to have suffered greatly. The Hairstreaks, comprising Chrysozephyrus Shirozu \& Yamamoto and Euaspa Moore in this area, were almost wiped out, as were Pratapa Moore and Tajuria Moore. Horaga onyx, which feeds on Coriaria nepanensis, a common plant in the area, was about, for I saw and photographed one of them and there were doubtless others of this elusive species about.

Panchala ganesa swarms by the hundred in ravines during May and June. It was about in greatly reduced numbers in 2009. Arhopala dodonea and A. rama, which are on the wing throughout the year lower down at $1500 \mathrm{~m}$ elevation, were about in their usual numbers. All these three species have been bred on Oak Quercus leucotrichophora in neighbouring Garhwal (WynterBlyth 1957) and this is presumably their hostplant in the area. Since A. dodonea and A. rama appear to have a brood during the winter months at $1500 \mathrm{~m}$ elevation, it is likely that they have a brood later than $P$. ganesa in Maheshkhan, too, although one would not expect them to have a winter brood in Maheshkhan considering that it snows there every year in winter.

The other butterflies that feed on Quercus leucotrichophora in the larval stage, Dophla patala and Sephisa dichroa, failed to appear in 2009. Since the trees were healthy and only deviated from normal in shedding their leaves in May, which is a month later than usual, it is assumed that the pupae of both these Nymphalids suffered due to desiccation.
For the remaining species, not enough is known about their early stages to understand their presence or absence during the summer of 2009. It is apparent, though, that sustained low atmospheric humidity levels are capable of drastically altering the composition of a butterfly community in high humidity areas.

The observations noted above strongly suggest that butterflies such as the Neptini, some Delias Hübner and Aporia Hübner species, etc, require a certain minimum level of atmospheric humidity to survive. If this falls below a certain level for a sufficient length of time, as during the winter of 2008-2009 (Table 2), the species can be exterminated from an area, despite the continued presence of their larval host plants.

The observations noted above draw attention to the importance of humidity levels for butterfly communities. As with the example of a chain, which is as strong as its weakest link, many butterfly species appear to require a certain minimum amount of atmospheric humidity throughout the year in order to survive in an area. A dry spell of even a few months can wipe out populations in an area, even if the dry spell falls during a period when most butterflies are in their pupae, which is usually considered the stage least susceptible to desiccation.

Even more drastic than low atmospheric humidity levels is the effect of forest fires in Himalayan broadleaf forests. Chir pine patches and forests in the area burn almost every year without any major effect on the butterfly community. In 2009 , for the first time, I saw broadleaf forest in the area burn: the effect was immediate and drastic, for the butterfly population was practically wiped out within the week.

\section{CONCLUSION}

Desiccation during the early stages is evidently one of the major factors preventing many butterfly species from colonising what would otherwise appear to be suitable habitat. Such species evidently require a minimum amount of atmospheric humidity throughout the year. If this requirement is not met, entire broods fail to emerge and a population can be wiped out. Atmospheric humidity levels are probably a major factor responsible for the restricted distribution of some butterflies that feed on widespread plants during the larval stage. Forest fires in Himalayan 
broadleaf forests are extremely destructive to butterfly communities in the area and are probably the most potent threat to butterfly communities in the short term. In the long term, habitat destruction is probably the most serious threat, since this results in the extinction of butterfly communities from an area.

\section{REFERENCES}

Anonymous (2010). Hydromet Division.India Metereological Department. http://www.imd.gov.in/section/hydro/ distrainfall/webrain/uttarakhand/nainital.txt. Accessed on 30 October 2010

Evans, W.H. (1932). The Identification of Indian Butterflies. 2nd Edition. Bombay Natural History Society, Bombay, $454 p p+32 p l$
Mackinnon P.W. \& L. de Nicéville (1897-1898). Butterflies from Mussoorie and the Dun Valley. Journal of the Bombay Natural History Society 11: 205-221; 368-389; 585-623.

Osmaston, A.E. (1927). A Forest Flora for Kumaon. Government Press, Allahabad, 34+605pp.

Peile, H.D. (1937). A guide to collecting butterflies of India. Staples, London, $14+312 \mathrm{pp}+25 \mathrm{pls}$.

Smetacek, P. (2002). The genus Pontia Fab. (Lep.: Pier.) in the Kumaon Himalaya. Journal of the Bombay Natural History Society 99 : 224-231.

Smetacek, P. (2010). Ypthima kedarnathensis A.P. Singh (Lepidoptera: Nymphalidae: Satyrinae) from the Kumaon Himalaya. Journal of Threatened Taxa 2(13): 1390-1391.

Wynter-Blyth, M.A. (1957). Butterflies of the Indian Region. Bombay Natural History Society, Bombay, xx $+523+72$ pls 